\title{
Effect of cetirizine on exercise induced asthma
}

\author{
S K Ghosh, C De Vos, I McIlroy, K R Patel
}

\begin{abstract}
The effect of oral and inhaled cetirizine, a potent and specific $H_{1}$ receptor antagonist, was studied in patients with exercise induced asthma. Twelve patients (five male; mean age 35.2 years) were given oral placebo or cetirizine $10 \mathrm{mg}$ twice daily for one week, double blind and in randomised order, and exercised on a treadmill for six to eight minutes at a submaximal work load two hours after the final dose. There was no significant change in baseline $\mathrm{FEV}_{1}$ after treatment and cetirizine failed to inhibit exercise induced bronchoconstriction (maximum falls in $\mathrm{FEV}_{1} 28 \%$ and $27 \%$ of baseline). In a further eight patients (four male; mean age 40.8 years) the effect of $1 \mathrm{ml}$ cetirizine (5 and $10 \mathrm{mg} / \mathrm{ml}$ ) given through a Wright nebuliser was compared with that of placebo in a double blind trial. The fall in FEV 1 after exercise was reduced after both concentrations of cetirizine by $15 \cdot 2 \%$ of baseline after $5 \mathrm{mg} / \mathrm{ml}$ and by $10 \cdot 2 \%$ after 10 $\mathrm{mg} / \mathrm{ml}$, compared with $23.7 \%$ after placebo. In two patients cetirizine had no effect. In a further study cetirizine (10 $\mathrm{mg} / \mathrm{ml}$ ) given by inhalation displaced the geometric mean $\mathbf{P C}_{20}$ histamine $13 \cdot 1$ fold to the right by comparison with placebo. The reason for the difference between the effects of oral and of inhaled cetirizine on exercise asthma is not clear but may be related to differences in local concentration in the airway.
\end{abstract}

The mechanism of increased airflow obstruction after exercise in patients with asthma remains unclear. Exercise induced asthma has been related to hyperventilation ${ }^{1}$ and subsequent airway cooling, ${ }^{2}$ and more recently to the rapid rewarming of airways during the recovery period. ${ }^{3}$ It is also not clear whether the thermal burden imposed on the airways during exercise has a direct effect on mast cells, leading to release of active mediators such as histamine, or whether it acts through an effect on the vagal irritant receptors. Increased plasma histamine concentrations and a rise in circulating neutrophil chemotactic activity have been found after exercise in asthmatic patients. ${ }^{4}$

We have investigated the role of histamine by the use of a potent and specific $\mathrm{H}_{1}$ receptor antagonist, cetirizine, given orally and by inhalation in exercise induced asthma.

\section{Methods}

We studied 20 patients with mild extrinsic asthma with documented exercise induced bronchoconstriction (fall in FEV over $^{20 \%}$ after treadmill exercise). All patients were non-smokers and all had positive skinprick test responses to at least three common inhaled allergens. None of the patients was taking oral corticosteroids, theophyllines, antihistamines, or anticholinergic drugs. Inhaled beta ${ }_{2}$ agonists and corticosteroids were stopped for at least 12 hours and inhaled sodium cromoglycate for 24 hours before each test. The study was approved by the hospital ethics committee and informed consent was obtained from each subject. Treatment was given in double blind, randomised manner. Airway responses were assesed by measuring FEV 1 with a dry wedge spirometer (Vitalograph, Buckingham), the best of three attempts being recorded for analysis.

\section{ORAL CETIRIZINE}

We compared the effect of one week's treatment with oral placebo and cetirizine $(10 \mathrm{mg}$ twice daily) on exercise induced asthma in 12 patients (five male; mean (SEM) age 35.2 (4.3) years). Patients were asked to take cetirizine or matched placebo for a week and to return on the eighth day after withholding the last dose. On arrival they had baseline $\mathrm{FEV}_{1}$ measured and the last dose of drug was given. $\mathrm{FEV}_{1}$ was measured again two hours later and the patient was then exercised on a treadmill for six to eight minutes at a submaximal work load (to achieve $80 \%$ of maximum age related heart rate). FEV repeated two, five, 10,15 , and 30 minutes after exercise. Room temperature on study days varied from $20^{\circ}$ to $22^{\circ} \mathrm{C}$ and relative humidity from $40 \%$ to $60 \%$. There was no significant difference in temperature and humidity on study days. The appropriate work load for each patient was determined at a preliminary visit and thereafter kept constant. The procedure was repeated with the alternative treatment after a washout period of at least two weeks.

\section{INHALED CETIRIZINE}

The effect of a single dose of 5 and $10 \mathrm{mg}$ of inhaled cetirizine $(5 \mathrm{mg} / \mathrm{ml}$ and $10 \mathrm{mg} / \mathrm{ml})$ was compared with that of placebo (phosphate buffered saline, $\mathrm{pH} \mathrm{7.4)}$ in a further eight patients (four male; mean age 40.8 (3.7) years). After having baseline $\mathrm{FEV}_{1}$ recorded patients were given $1 \mathrm{ml}$ of cetirizine ( 5 or $10 \mathrm{mg} / \mathrm{ml}$ ) or matched placebo (phosphate buffered saline as before) through a Wright nebuliser (nebuliser volume $4 \mathrm{ml}$, output $0.133 \mathrm{ml} / \mathrm{min}$ at a flow rate of 9 litres $/ \mathrm{min}$, and pressure $50 \mathrm{lb} / \mathrm{in}^{2}, 344.4 \mathrm{kPa}$ ). The treatments were given double blind and in randomised

\section{Western Infirmary, \\ S K Ghosh \\ K R Patel \\ UCB \\ Belgium}

Reprint requests to: Dr Patel

Accepted 11 January 1991 
Age, sex, work load, and maximum percentage fall in FEV, after exercise challenge with placebo and cetirizine given orally and by inhalation

\begin{tabular}{|c|c|c|c|c|c|c|c|}
\hline $\begin{array}{l}\text { Patient } \\
\text { No }\end{array}$ & Age & Sex & $\begin{array}{l}\text { Work load } \\
(\mathrm{kpm} / \mathrm{min})\end{array}$ & Placebo & \multicolumn{3}{|c|}{ Cetirizine } \\
\hline \multicolumn{8}{|c|}{ ORAL CETIRIZINE ( $10 \mathrm{mg}$ twice daily) } \\
\hline 1 & 26 & $\mathbf{M}$ & 1866 & -47 & \multicolumn{3}{|c|}{-24} \\
\hline 2 & 28 & $\mathbf{F}$ & 881 & -25 & \multirow{2}{*}{\multicolumn{3}{|c|}{$\begin{array}{l}-21 \\
-37\end{array}$}} \\
\hline 3 & 25 & $\mathbf{M}$ & 1279 & -8 & & & \\
\hline 4 & 50 & $\mathbf{F}$ & 740 & -40 & \multicolumn{3}{|c|}{-8} \\
\hline 5 & 23 & $\mathbf{F}$ & 679 & -38 & \multicolumn{3}{|c|}{-46} \\
\hline 6 & 51 & $\mathbf{F}$ & 1009 & -28 & \multicolumn{3}{|c|}{-42} \\
\hline 7 & 32 & $\mathbf{M}$ & 1597 & -39 & \multicolumn{3}{|c|}{-23} \\
\hline 8 & 51 & $\mathbf{F}$ & 1052 & -17 & \multicolumn{3}{|c|}{-27} \\
\hline 9 & 45 & $\mathbf{F}$ & 967 & -26 & \multicolumn{3}{|c|}{-21} \\
\hline 10 & 53 & $\mathbf{M}$ & 991 & -26 & \multicolumn{3}{|c|}{-32} \\
\hline 11 & 34 & $\mathbf{F}$ & 1040 & -10 & \multicolumn{3}{|c|}{-25} \\
\hline 12 & 19 & $\mathbf{M}$ & 1609 & -36 & \multicolumn{3}{|c|}{-16} \\
\hline Mean & \multirow{3}{*}{\multicolumn{2}{|c|}{$\begin{array}{r}35 \cdot 2 \\
4 \cdot 3\end{array}$}} & 1143 & $-28 \cdot 2$ & \multirow{3}{*}{\multicolumn{3}{|c|}{$\begin{array}{l}-27 \\
\mathrm{NS}^{3 \cdot 3}\end{array}$}} \\
\hline SEM & & & 99 & $4 \cdot 2$ & & & \\
\hline & & & & & & & \\
\hline \multicolumn{8}{|c|}{ INHALED CETIRIZINE ( 5 and $10 \mathrm{mg}$ ) } \\
\hline \multirow{8}{*}{$\begin{array}{l}13 \\
14 \\
15 \\
16 \\
17 \\
18 \\
19 \\
20\end{array}$} & & & & & \multirow{8}{*}{$\begin{array}{l}5 m g \\
-16 \cdot 9 \\
-17 \cdot 0 \\
-12 \cdot 3 \\
-4 \cdot 9 \\
-16 \cdot 1 \\
-13 \cdot 8 \\
-14 \cdot 7 \\
-26 \cdot 2\end{array}$} & \multirow{8}{*}{$\begin{array}{r}10 m g \\
-4.0 \\
-16.9 \\
+5.7 \\
+8.9 \\
-33.3 \\
-8.4 \\
-8.5 \\
-25.8\end{array}$} & \\
\hline & 43 & $\mathbf{F}$ & $\begin{array}{r}1089 \\
826\end{array}$ & $-24 \cdot 8$ & & & \\
\hline & 53 & $\mathrm{~F}$ & 881 & $-16 \cdot 5$ & & & \\
\hline & 48 & $\mathbf{F}$ & 1016 & $-14 \cdot 8$ & & & \\
\hline & 44 & $\mathbf{M}$ & 1383 & $-21 \cdot 7$ & & & \\
\hline & 24 & $\mathbf{M}$ & 1308 & $-42 \cdot 4$ & & & \\
\hline & 51 & F & 1144 & $-18 \cdot 8$ & & & \\
\hline & 32 & $\mathbf{M}$ & 1438 & $-29 \cdot 4$ & & & \\
\hline Mean & $40 \cdot 8$ & & 1210 & $-23 \cdot 7$ & $-15 \cdot 2$ & $-10 \cdot 3$ & \\
\hline SEM & $3 \cdot 7$ & & 105 & $3 \cdot 1$ & $2 \cdot 1$ & $5 \cdot 1$ & \\
\hline$p^{\star}$ & & & & & 0.05 & 0.05 & \\
\hline
\end{tabular}

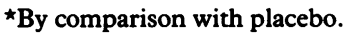

kpm-kilopond metre. recorded 30, 60, and 90 seconds after each inhalation and the procedure repeated until the $\mathrm{FEV}_{1}$ had fallen at least $20 \%$ below the lowest $F E V_{1}$ value recorded after inhalation of buffered saline. The results were expressed as the concentration producing a $20 \%$ fall in $\mathrm{FEV}_{1}\left(\mathrm{PC}_{20}\right)$, obtained from the dose-response curve.

\section{ANALYSIS}

The $\mathrm{PC}_{20}$ values were log transformed before analysis. The maximal changes in $\mathrm{FEV}_{1}$ after exercise were calculated from post-drug baseline values. The maximal falls in FEV after the exercise challenge in the oral cetirizine study were compared by Student's $t$ test. The maximal percentage falls in FEV, after exercise and different concentrations of inhaled cetirizine and placebo and the changes in $\mathrm{PC}_{20}$ histamine were compared by analysis of variance.

\section{Results}

\section{ORAL CETIRIZINE}

The mean (SEM) $\mathrm{FEV}_{1}$ was $91.0 \%(2.3 \%)$ of predicted at entry to the study. The mean pretreatment baseline $\mathrm{FEV}_{1}$ was $3.05(0.24) 1$ on the placebo day and $2.94(0.23) 1$ on the cetirizine day. Two hours after treatment FEV was similar after placebo and after cetirizine at $3.18(0.28)$ and $3.16(0.33) 1$ (table). Neither placebo nor cetirizine caused a significant change in $\mathrm{FEV}_{1}$. The mean maximum $\%$ fall in $\mathrm{FEV}_{1}$ after exercise was $28 \cdot 2(4 \cdot 1)$ and $27 \cdot 0$ (3.3) with placebo and cetirizine respectively. The difference was not significant.

\section{INHALED CETIRIZINE}

The mean (SEM) FEV was $83.0 \%(3 \cdot 1 \%)$ of predicted at entry to the study. Mean FEV values were $2.84(0.27) 1$ with placebo, 2.94 $(0.28) 1$ with cetirizine $5 \mathrm{mg} / \mathrm{ml}$, and $2.82(0.27)$ 1 with cetirizine $10 \mathrm{mg} / \mathrm{ml}$ before treatment and $2.94(0.23), 2.98(0.27)$, and 2.94 (0.33) 130 minutes after inhalation of the drugs. There was no significant difference in baseline $\mathrm{FEV}_{1}$ on the three study days and neither placebo nor either concentration of cetirizine caused a significant change in the resting $\mathrm{FEV}_{1}$.

The mean (SEM) maximum \% fall in $\mathrm{FEV}_{1}$ after exercise was $23 \cdot 7(3 \cdot 1), 15 \cdot 2(2 \cdot 1)$, and $10 \cdot 2(5 \cdot 1)$ with placebo and 5 and $10 \mathrm{mg} / \mathrm{ml}$ cetirizine (figure). The difference between both concentrations of cetirizine and placebo was significant $(p<0.05)$; there was no significant difference between the two doses of cetirizine. Six patients showed protection with cetirizine, the mean (SEM) maximum \% fall in FEV after exercise being $23(4 \cdot 1), 13(1 \cdot 8)$, and $3 \cdot 8$ (3.9) with placebo and 5 and $10 \mathrm{mg} / \mathrm{ml}$ cetirizine.

The geometric mean $\mathrm{PC}_{20}(95 \%$ confidence interval) for histamine was $0.6(0 \cdot 27-1 \cdot 3)$ after placebo and $8 \cdot 16(3 \cdot 16-21 \cdot 08)$ after $10 \mathrm{mg}$ inhaled cetirizine. Cetirizine caused a $13 \cdot 1$ fold shift to the right in the dose-response curve by comparison with placebo $(p<0.001)$.
Inhibition $(p<0.05)$ of the fall in $F E V_{1}$ after exercise by inhaled cetirizine ( 5 and 10 $\mathrm{mg} / \mathrm{ml}$ ) by comparison with placebo. There was no significant difference between 5 and 10 $\mathrm{mg} / \mathrm{ml}$ cetirizine.

\section{Discussion}

The increased losses of heat or water or both 
from the respiratory tract that result from hyperventilation have been suggested as possible triggers of exercise induced asthma. ${ }^{6}$ Breathing cold air during exercise has been shown to potentiate exercise induced asthma. ${ }^{27}$ Anderson and colleagues have suggested that airway water loss is a potent stimulus in exercise induced asthma, having shown that inhalation of hyperosmolar aerosol can induce bronchoconstriction in patients with asthma. ${ }^{89}$ The most convincing evidence that respiratory heat loss in itself is not an adequate explanation of exercise asthma comes from a series of studies showing that hyperventilation or exercise with hot dry air is as potent a stimulus of bronchoconstriction as is hyperventilation with cold dry air. ${ }^{10-12}$ Noviski and colleagues ${ }^{13}$ have shown that part of the bronchoconstriction may be related to the intensity of exercise rather than to change in the temperature or osmolarity of the respiratory tract.

The link between respiratory heat loss and exercise induced bronchoconstriction is not yet clear, and both reflex vagal and humoral mechanisms have been suggested. Mediator release from the lung mast cells may play a part as increased plasma histamine and neutrophil chemotactic activity have been found after exercise. ${ }^{4}$ Attenuation of the bronchoconstrictor response to repeated exercise challenges at short intervals also supports depletion of mediator stores from mast eells. ${ }^{14}$.

Although histamine has been implicated as a mediator in exercise induced asthma, the use of antihistamines to prevent an exercise induced bronchoconstrictor response has generally been disappointing. This may in part be related to failure to achieve a sufficient concentration of antihistamines at lung $\mathrm{H}_{1}$ receptor sites, as older antihistamines could not be given in high doses because they caused sedative and anticholinergic side effects. The results with the newer $\mathrm{H}_{1}$ receptor antagonists in exercise induced asthma have been varied. Inhaled clemastine $^{15}$ and oral astemizole have been reported to protect against exercise induced asthma ${ }^{16}$ whereas ketotifen, despite its pronounced antihistaminic properties, failed to show any effect. ${ }^{1718}$ Terfenadine ${ }^{19}$ and azelastine $^{20}$ have been shown to modify exercise induced asthma, though the protective effect of terfenadine was observed only with higher doses.

Cetirizine $2 \mathrm{HCl}$, a derivative of hydroxyzine, is a potent and selective $H_{1}$ antagonist and in a recent study ${ }^{21}$ we found a 74 fold shift of the histamine dose-response curve to the right after a single oral dose of $15 \mathrm{mg}$. It is free of anticholinergic and antiserotonin effect. ${ }^{22}$ Studies in vitro have shown that it inhibits human basophil anti-IgE induced degranulation and in the rat peritoneal mast cell activation by substance $P .{ }^{23}$ In the present study we have been unable to find any protection against exercise induced asthma after one week's treatment with oral cetirizine. In contrast, a single 1 $\mathrm{ml}$ dose of inhaled cetirizine at $5 \mathrm{mg} / \mathrm{ml}$ and 10 $\mathrm{mg} / \mathrm{ml}$ caused significant protection against exercise induced asthma in six of the eight patients studied. There was a suggestion of a dose-response effect in these six patients. The difference in the protection between the inhaled and the oral route is difficult to explain. One possibility is that increased local concentrations by the inhaled route stabilise airway mast cells. Similar differences have been observed with frusemide given by inhalation and orally in patients with exercise induced asthma. ${ }^{24}$ Further studies of inhaled and oral cetirizine in experimental asthma may help to elucidate these differences.

We thank Mrs J Peter for secretarial assistance; UCB Pharmaceuticals, Belgium, for the supply of cetirizine powder; and Mrs Heather Ambler for technical assistance.

1 Zeballos RJ, Shturman-Ellstein R, McNally JF, Hirsch EJ, Southrada JF. The role of hyperventilation in exerciseinduced bronchoconstriction. Am Rev Respir Dis 1978;118:877-84.

2 Deal EC, McFadden ER, Ingram RH, Strauss RH, Jaeger $\mathrm{JJ}$. Role of respiratory heat exchange in production of exercise-induced asthma. $J$ Appl Physiol 1979;46:467-75.

3 McFadden ER, Lenner KA, Strohl KA. Post exertional airway rewarming and thermally induced asthma. $J$ Clin Invest 1986;78:18-25.

4 Lee TH, Brown MJ, Nagy L, Causon R, Walport MJ, Kay AB. Exercise-induced release of histamine and neutrophil chemotactic factors in atopic asthmatics. J Allergy Clin Immunol 1982;70:73-81.

5 Cockcroft DW, Killian DN, Melon JJA, Hargreave FE. Bronchial reactivity to inhaled histamine: a method and clinical survey. Clin Allergy 1977;7:235-43.

6 Chen WY, Horton DJ. Heat and water loss from the airways and exercise induced asthma. Respiration 1977;34:305-13.

7 Strauss RH, McFadden ER Jr, Ingram RH Jr, Deal EC Jr, Jaeger J. Influx of heat and humidity on the airway obstruction induced by exercise in asthma. $J$ Clin Invest 1978;61:433-40.

8 Anderson S, Schoeffel RE, Follet R, Percy CP, Daviskas F, Kendall $M$. Sensitivity to heat and water loss at rest and during exercise in asthmatic patients. Eur J.Respir Dis during exercise
1982;63:459-71.

9 Schoeffel RE, Anderson SD, Altounyan REC. Bronchial hyperreactivity in response to inhalation of ultrasonically nebulised solutions of distilled water and saline. $\mathrm{Br} \mathrm{Med}$ 1981;283:1285-7.

10 Hahn A, Anderson SD, Morton AR, Black JL, Fitch KD. A reinterpretation of the effect of temperature and water content of inspired air in exercise induced asthma. Am Rev Respir Dis 1984;130:575-9.

11 Aitken ML, Marini JJ. Effect of heat delivery and extraction on airway conductance in normal and asthmatic subjects. Am Rev Respir Dis 1985;131:357-61.

12 Eschenbacher WL, Sheppard D. Respiratory heat loss is no the sole stimulus for bronchoconstriction induced by isocapnic hyperpnoea with dry air. Am Rev Respir Dis 1985;131:894-901.

13 Noviski N, Bar-Yishay E, Gur 1, Godfrey S. Exercise intensity determines and climatic conditions modify the severity of exercise induced asthma. Am Rev Respir Dis 1987;136:592-4.

14 Edmunds AT, Tooley M, Godfrey S. The refractory period after exercise induced asthma: its duration and relation to the severity of exercise. Am Rev Respir Dis 1978;117: 247-54.

15 Hartley JPR, Norgrady SG. Effect of an inhaled antihistamine on exercise-induced asthma. Thorax 1980;35: 593-4.

16 Clee MD, Ingram CG, Reid PC, Robertson AS. The effect of astemizole on exercise induced asthma. $\mathrm{Br} J \mathrm{Dis}$ Chest 1984;78:180-3.

17 Petheram IS, Moxham J, Bierman CW, McAllen M, Spiro SG. Ketotifen in atopic asthma and exercise-induced asthma. Thorax 1981;36:308-12.

18 Dorward AJ, Patel KR. Inhaled ketotifen in exercise induced asthma-a negative report. Eur $J$ Respir Dis 1985;67:378-80.

19 Patel KR. Terfenadine in exercise-induced asthma. $B M$ 1984;288:1496-7.

20 Mangussen H, Reuss G, Jorres A, Aurich R. Effect of azelastine on exercise-induced asthma. Chest 1988 93:937-40.

21 Ghosh SK, De Vos C, McIlroy I, Patel KR. Effect of cetirizine on histamine and leukotriene $\mathrm{D}_{4}$ induced bronchoconstriction in patients with atopic asthma. $J$ Allergy Clin Immunol (in press).

22 Snyder SH, Snowman AM. Receptor effects of cetirizine. Ann Allergy 1987;59 (part II): 4-8.

$23 \mathrm{De}$ Vos C, Maleux MR, Gobert J. In vitro pharmacological profile of cetirizine. $2 \mathrm{HCl}$, a new non-sedating antiallergic drug [abstract]. Allergologia and Immunologia Clinica 1987;2(2):82.

24 Bianco S, Vaghi A, Robuschi M, Pasarqiklian M. Prevention of exercise induced bronchoconstriction by inhaled furosemide. Lancet 1988;ii:252-5. 